\title{
Increase in wheat production through management of abiotic stresses : A review
}

\author{
Mamta Kajla ${ }^{\text {, Vinaya Kumar Yadava, Jaswant Khokhar }}{ }^{\mathrm{c}}$, Samar Singh ${ }^{\mathrm{b}}$, R. S. Chhokar ${ }^{\mathrm{a}}$, \\ Raj Pal Meena ${ }^{a}$, R. K. Sharma ${ }^{a}$
}

${ }^{a}$ ICAR-Indian Institute of Wheat and Barley Research, Karnal-132001 (Haryana) INDIA

${ }^{\mathrm{b}}$ CCS Haryana Agricultural University, KVK, Karnal -132001 ( Haryana) INDIA

${ }^{\mathrm{c}}$ University of Nottingham, School of Biosciences-LE125RD UK

*Corresponding author. E-mail: mamtakajla@yahoo.com

Received: March 12, 2015; Revised received: August 15, 2015; Accepted: October 9, 2015

Abstract: About $9 \%$ of area on earth is under crops out of which $91 \%$ is under various stresses. On an average, about $50 \%$ yield losses are due to abiotic stresses mostly due to high temperature $(20 \%)$, low temperature $(7 \%)$, salinity $(10 \%)$, drought (9\%) and other abiotic stresses (4\%). As there is no scope for increasing area under agriculture, the increased productivity from these stressed land is a must to meet the ever increasing demand. Further, the severity of abiotic stresses is likely to increase due to changing climate leading to adverse effect on crops. Therefore, abiotic stresses like drought, salinity, sodicity, acidity, water logging, heat, nutrient toxicities/ deficiencies etc need to be effectively addressed through adoption of management practices like tillage and planting options, residue management, sowing time, stress tolerant cultivars, irrigation scheduling and integrated nutrient management to conserve natural resources, mitigating their adverse effect and sustainable wheat production.

Keywords: Abiotic stresses, Irrigation scheduling, Residue retention, Nutrient management, Tillage

\section{INTRODUCTION}

Globally, only $9 \%$ of the area is conducive for crop production, out of which $91 \%$ is under different stresses. Wheat (Triticum aestivum L.) which is world's third largest crop after maize and rice occupies about 218.5 million hectare which is roughly $4 \%$ of the global area conducive for crop production, with an average yield of $3.26 \mathrm{t} \mathrm{ha}^{-1}(\mathrm{FAO}, 2014)$. With increased global population and changes in consumption preferences there has been substantial increase in demand for wheat during the past 50 years. Worldwide, $222 \mathrm{Mt}$ of wheat was being produced during 1961 which increased to $713 \mathrm{Mt}$ during 2013 (Fig. 1). The corresponding increase in India was from 10.9 Mt to $94 \mathrm{Mt}$ (Fig. 2) during this time period (USDA, 2014). Significant increase in wheat production was due to the Green Revolution in mid 1960s, which involved the adoption of semi-dwarf high-yielding varieties of wheat coupled with appropriate management practices for achieving greater productivity.

Introduction of semi dwarf high yielding varieties no doubt has increased the production of food crops by many folds but also resulted in depletion of natural resources due to their exhaustive exploitation.This ultimately caused imbalance to the ecology thus, inviting problems of abiotic stresses. The most popular abiotic stresses are, high temperature, drought, flood and other natural disasters. The lesser known stressors i.e. poor edaphic conditions, high radiation, compac- tion, contamination, rapid dehydration during seed germination etc, generally occur on a smaller scale and so are less noticeable. If more than one abiotic stresses occur together then their effect is more deleterious than their single occurrence effect. According to world estimates, an average of $50 \%$ yield losses in agricultural crops are due to abiotic factors like high temperature $(20 \%)$, low temperature $(7 \%)$, salinity $(10 \%)$, drought (9\%) and other forms of stresses (4\%) (Oerke et al., 1994 and Thilert, 2006).

Among Southeast Asian countries like India, are more challenged with multitude combinations of several abiotic stresses. These countries are facing reducing trend in productivity due to frequent droughts, floods, degradation of land, fluctuating temperature etc. Thus, the main task ahead is to protect/ save natural resources from being depleted, so as to maintain sustainability in production or to attain a goal of food security of the nation. As wheat is the important food crop of these countries, so our due focus was to sustain wheat production which can be done by mitigating the effect of commonly occurring abiotic stresses.

To ameliorate the effect of abiotic stresses on the production of wheat crop, one should know about the types of abiotic stressors (Fig.3) and opt for better agronomic management practices to alleviate their effect. The use of tillage methods like No-Till, Zero tillage with or without residue retention not only helps to mitigate the effects of high temperature stress but also helps in conserving moisture and organic matter in the 
field, thereby maintaining the soil health of the field. Early sowing or timely sowing of crop can save one irrigation in wheat crop by utilizing the residual moisture available in soil after harvest of paddy crop and also helps crop in escaping terminal heat stress. The use of different irrigation methods like sprinkler irrigation and drip irrigation gives good crop yield utilizing scarce water resources and saline water for irrigation. The nutrient management options like INM, site specific nutrient management, use of NDVI for nitrogen application and fertilizer application on the basis of soil test values helps in correcting nutrient deficiencies and toxicity in the soil as well as in plant. Therefore, the above management options can be used as tools to mitigate the effect of upcoming abiotic stresses in wheat production which is the need of hour and concerted efforts are made to do research in this area to sustain productivity on ecological basis.

\section{TYPES OF ABIOTIC STRESSES AND METHODS TO MITIGATE THEIR EFFECT}

Soil degradation: It is one of the severe problem in Southeast Asian countries with high demographic pressure. For preventing soil degradation, the main issues are, controlling soil erosion, preventing eutrophication of surface water and contamination of groundwater, combating desertification and enhancing soil carbon sequestration to improve the soil quality/productivity. More than 800 million hectares of lands throughout the world are salt-affected (including both saline and sodic soils), equating to more than $6 \%$ of the world's total land area (FAO, 2010). Among the south-east Asian countries like India, approximately 25 Mha of soils are affected by soil acidity which is $30 \%$ of the current area under cultivation (Sharma et al., 2012). And about, 6.7 Mha land is affected by salt stresses including 3 Mha by salinity and 3.7 Mha by alkalinity, distributed in 15 of the 29 states. Crops grown on acidic soils $(\mathrm{pH}<5.5)$ typically suffers from aluminium $(\mathrm{Al})$ toxicities and deficiencies of phosphorus (P), boron (B) and molybdenum (Mo) (Mora et al., 2007, Poschenrieder et al, 2008 ) and thus have very low productivity. These soils need to be reclaimed and fertilized time to time to ensure adequate supplies of nutrients to crops. Amendments like application of gypsum is essential to reclaim alkali soils while appreciable leaching of salts and use of efficient sub-surface drainage system is required for saline-waterlogged soils.. Approximately, $12 \mathrm{M}$ ha area is waterlogged and floods prone, where productivity of arable crops gets severely affected. Hence the challenge is to develop best combinations of resource management practices to combat these edaphic stress prone areas.

Soil pH: Soil $\mathrm{pH}$ is a measure of the acidity and alkalinity in soils. $\mathrm{pH}$ levels range from 0 to 14 , with 7 being neutral, below 7 acidic and above 7 alkaline. The optimal $\mathrm{pH}$ range for most of the plants is between 5.5 and 7.0; however, many plants can thrive at $\mathrm{pH}$ values outside this range. Soil $\mathrm{pH}$ affects the soil's physical, chemical, and biological properties and processes, as well as plant growth. Because $\mathrm{pH}$ levels control many chemical processes that take place in the soil - specifically, plant nutrient availability, so it is vital to maintain proper $\mathrm{pH}$ level for getting full yield potential of a plant. The amendments done to maintain $\mathrm{pH}$ level as required by the plant differs with respect to the type of soils and are discussed in detail as under:-

Soil acidity: Soil acidity is one of the most yieldlimiting factors for crop production. Theoretically; soil acidity is quantified on the basis of hydrogen $\left(\mathrm{H}^{+}\right)$and aluminium $\left(\mathrm{Al}^{3+}\right)$ concentrations of soils. For crop production, however, soil acidity is a complex of numerous factors involving nutrient/element deficiencies and toxicities, low activities of beneficial microorganisms, and reduced plant root growth which limits absorption of nutrients and water. In addition, acid soils have low water-holding capacity and are subject to compaction and water erosion (Fageria and Baligar, 2003). Soils become acidic when basic elements such as calcium, magnesium, sodium and potassium held by soil colloids are replaced by hydrogen ions. Soils formed under conditions of high annual rainfall are more acidic than are soils formed under more arid conditions (Mohebbi and Mahler, 1988). Thus, most of the southeastern soils are inherently more acidic in nature than soils of the Midwest and far West. Plant available forms of $\mathrm{N}, \mathrm{S}$ and $\mathrm{P}$ are reduced in acidic soils, and in symbiotic $\mathrm{N}$ fixation by leguminous crops because nutrient transformations and nitrogen fixation are restricted in acidic soils, which is due to reduced activity of the microorganisms that are responsible for carrying these processes. The availability of nutrients to plants is altered by soil $\mathrm{pH}$ (Figure 4).

In acidic soils, the availability of the major plant nutrients nitrogen, phosphorous, potassium, sulphur, calcium, magnesium and also the trace element molybdenum gets reduced and on the other hand the availability of iron, manganese, copper, zinc and aluminium are also higher in acidic soils and may become toxic. Ap-

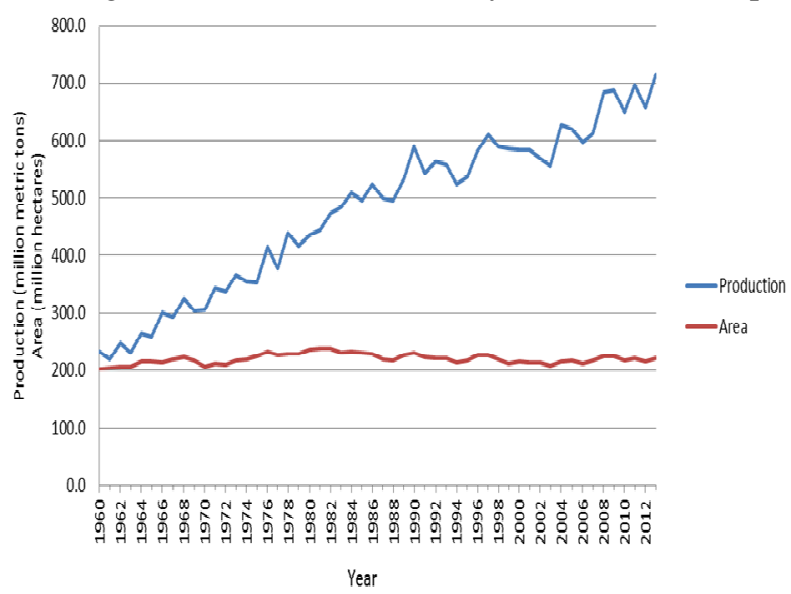

Fig. 1. Global wheat area and production (Source: 19602013; USDA 2014) 
plication of lime to such soils helps in raising their $\mathrm{pH}$ and thus maintains the optimum availability of these nutrients.

\section{Factors affecting soil acidity}

Rainfall: Water $\left(\mathrm{H}_{2} \mathrm{O}\right)$ in the form of rain drops combines with carbon dioxide $\left(\mathrm{CO}_{2}\right)$ to form a weak acid-carbonic acid $\left(\mathrm{H}_{2} \mathrm{CO}_{3}\right)$. The weak acid ionizes, releasing hydrogen $\left(\mathrm{H}^{+}\right)$and bicarbonate $\left(\mathrm{HCO}_{3}\right)$. The released hydrogen ions replace the calcium ions held by soil colloids, causing the soil to become acidic. The displaced calcium $\left(\mathrm{Ca}^{++}\right)$ions combine with the bicarbonate ions to form calcium bicarbonate, which, being soluble, is leached from the soil. The net effect is increased soil acidity.

Nitrogen Fertilizers: Long-term use of ammonium fertilizers, removal of cations in the harvested portion of crops and leaching process, and release of organic acids in decomposition of crop residues and added organic wastes decrease soil $\mathrm{pH}$ resulting in soil acidity (Fageria and Baligar., 2005). Use of adequate amounts of nitrogen fertilizer is fundamental for higher yield of crops under all ecosystems. Urea and ammonium sulfate are dominant nitrogen carriers used for crop production around the world. The acidification of soils by using the ammonium form of nitrogen fertilizers can be explained by the following equation:
$\mathrm{NH}_{4}^{+}+2 \mathrm{O}_{2}$
$\mathrm{NO}_{3}{ }^{-}+2 \mathrm{H}_{2} \mathrm{O}+2 \mathrm{H}^{+}$

The oxidation of $\mathrm{NH}_{4}{ }^{+}$in the above equation is known as nitrification which is carried by heterotrophic and autotrophic bacteria. The most important autotrophic genera of bacteria are Nitrosomonas and Nitrobacter. Use of legume crops continuously or in rotation can increase soil acidity.

Amendments to correct soil acidity: Liming- Soil acidity has a negative effect on crops mainly through $\mathrm{P}$ unavailability from $\mathrm{P}$ fixation in soils because the $\mathrm{Fe}$ and Al soil components (sesquioxides) fixes sizeable quantity of $\mathrm{P}$. Excess $\mathrm{Al}^{3+}$ ions from soil acidity tend to accumulate in plant roots and thereby prevent $\mathrm{P}, \mathrm{Mo}$ and other ions translocation to the tops from the roots, as evidenced by the inhibition of root elongation and

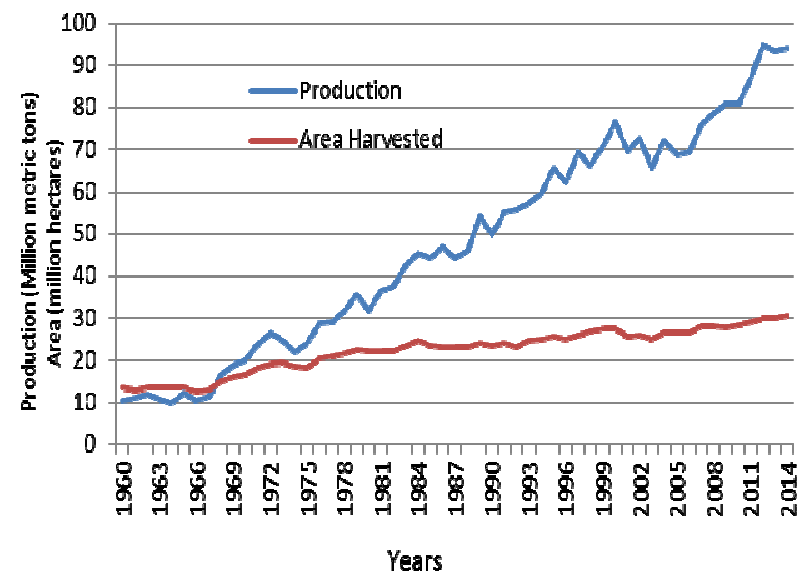

Fig. 2. Wheat area and production in India (Source: 19602013; USDA, 2014). overall retarded crop development (Kochian et al., 2004, Kanyanyua et al., 2002, Ligeyo and Gudu, 2003-05). The detrimental effect of $\mathrm{H}+$ ions is not as distinct as that of $\mathrm{Al}^{3+}$ cations, but excess of $\mathrm{H}+$ ions in acid soils affects plant root membrane permeability and therefore interferes with ion transport (Ligeyo and Gudu, 200305). So, application of lime increases soil $\mathrm{pH}$ and decreases exchangeable $\mathrm{Al}$ and available $\mathrm{Fe}$ and $\mathrm{Zn}$ ions, thereby increases translocation of $\mathrm{P}, \mathrm{Cu}, \mathrm{Mn}$ and other nutrient ions. This resulted in overall increase in biomass production and grain yield of wheat crop (Tsadilas et al., 1995. The increament in wheat grain was recorded using 1 tonn $\mathrm{ha}^{-1}$ limes treatment despite the soil $\mathrm{pH}$ profile being similar to the un-limed control. It was observed that the un-limed treatment had the most weeds so, the reason for increament may be the less weed competition for water and nutrients under 1 tonn ha $^{-1}$ lime treatment. (Chris and Joel, 2010).

Soil alkalinity: Soils having $\mathrm{pH}$ greater than 7 are considered as alkaline soils. Alkaline soils are sometimes referred to as "sweet. Alkali, or alkaline, soils are claysoils with high $\mathrm{pH}(>8.5)$, having poor soil structure and a low infiltration capacity (Bolt, 1981). Often they have a hard calcareous layer at 0.5 to 1 meter depth. Alkali soils owe their unfavorable physico-chemical properties mainly due to the dominating presence of sodium carbonate which causes the soil to swell and difficult to settle. They derive their name from the alkali metal group of elements to which the sodium belongs and that can induce basicity.

Factors causing soil alkalinity: The causes of soil alkalinity are both natural and man-made. The natural development is due to the presence of soil minerals producing sodium carbonate upon weathering. The man-made development is due to the application of irrigation water (surface or ground water) containing a relatively high proportion of sodium bicarbonates) and repeated addition of lime to soil without its need.

Problems due to soil alkalinity: Alkali soils are difficult to take into agricultural production. Rainwater stagnates on these soils easily and, in dry periods, soils become too hard. Crop production is limited to crops tolerant to surface water logging (e.g. rice, grasses) and the productivity is low.

Amendments to correct soil alkalinity: Alkali/sodic soils with solid $\mathrm{CaCO}_{3}$ can be reclaimed with grass cultures, ensuring the incorporation of mulch acidifying organic material into the soil,

Leaching of the excess sodium.

Deep ploughing and incorporating the calcareous subsoil into the top soil.

By adding acidifying minerals like pyrite

Use of gypsum, because it reacts with sodium carbonate to convert into sodium sulphate which is a neutral salt and does not contribute to high pH (Chhabra et al., 1996). Where urea is available cheaply to farmers, it can also used to reduce the soil alkalinity / salinity primarily (Abrol et al., 2012). The $\mathrm{NH}_{4}$ (Ammonium) present in urea which is a weak cation releases the strong cation 
$\mathrm{Na}$ from the soil structure into water. Thus alkali soils absorb / consume more urea compared to other soils. Most efforts are therefore directed to improve the top layer only (first $10 \mathrm{~cm}$ of the soils), as the top layer is most sensitive to structure deterioration (Chhabra et al., 1996).

Soil salinity: Soluble salts provide most of the elements essential for plant growth, but their excessive levels can be injurious. So, soluble salts when present in excess amount and became injurious to plant, the soil is said to be saline. Saline soils usually contain a mixture of salt constituents such as chlorides, sulfates, carbonates and bicarbonates of sodium, calcium and magnesium. The proportions may vary widely from place to place depending on source of salts.

Salt affected soils are commonly found in arid and semi-arid regions, where annual precipitation is insufficient to meet the evapotranspiration demand /needs of plants. As a result, salts remain in the soil layer and do not get leached down, and they remained in the amount which is detrimental to the plant growth.

Since, the saline soils have abundant nutrient reserve due to less removal by plants and yearly addition of fertilizers, they have potential productivity if amendments done timely and correctly

Effects of soil salinity: Saline soils have friable structure Permeability of soil to water and air is restricted.

Salinity affects plants in different ways such as osmotic effects, specific-ion toxicity and/or nutritional disorders (Lauchli and Epstein, 1990).

Salt stress retarded leaf development and tillering but hastened plant maturity.

Grain yields were maximized when salt stress was

\section{Abiotic Stressors}

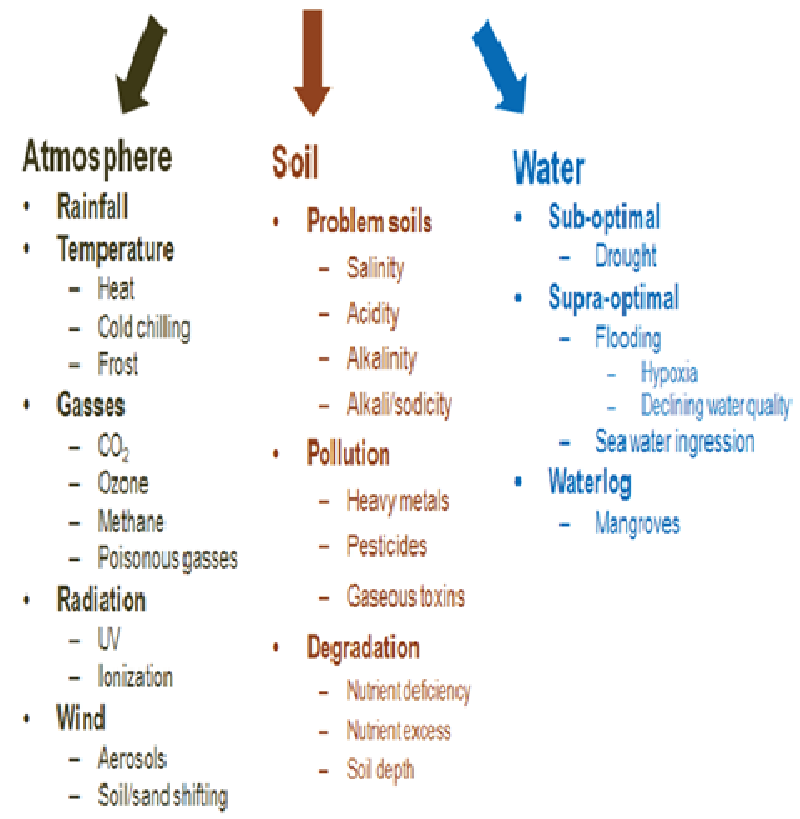

Fig. 3. Abiotic stressors affecting Indian Agriculture (Source: Vision 2030, NIASM) delayed until after the terminal spike formation or by withdrawing stress at the late leaf primordial stage or double ridge stage.

Also, short periods of salt stress during organogenesis have irreversible consequences on wheat growth and development (Grieve et al.,2001). Salt stress hastens reproductive development but adversely affects spike development and decrease the yield potential of wheat. Amendments to correct soil salinity: ScrapingScraping of salts by using mechanical ways improves plant growth temporarily, as the salts accumulate again and again.

Flushing: In soils having crust and low permeability, washing away the surface salts by flushing good quality water over the surface is helpful in removing the salts.

Leaching: leaching of salts using irrigation or rain water is the only practical way to remove excess salts from the soil. Leaching works well on saline soils having good structure and internal drainage. To leach a highly saline soil, one need to apply as much as 48 acre-inches of water. An acre-inch is the volume of water that would cover 1 square acre to a depth of 1 inch (27,152 gallons).

Improving drainage: In soils with poor drainage, deep tillage helps to break up the soil surface as well as clay pans and hardpans, that restricts the downward flow of water.

Reducing evaporation: Applying residue or mulch to the soil reduces evaporation losses, thus decreases the accumulation of surface salts ( Provin and Pitt, 2001).

Moisture stress: Water is becoming scarce not only in arid and drought prone areas but also in regions where rainfall is abundant. Plants experience water stress either when the water supply to their roots becomes limiting, or when the transpiration rate becomes intense. Water stress is primarily caused by a water defi-

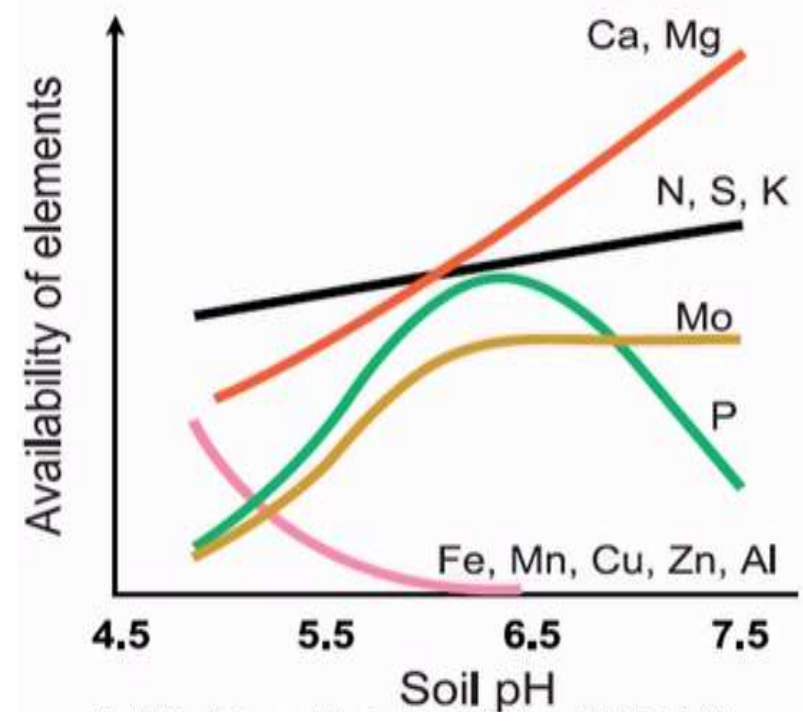

Fig. 4. Relationship between soil $p H$ and nutrient availability (Source: DAFWA Bulletin 4784). 


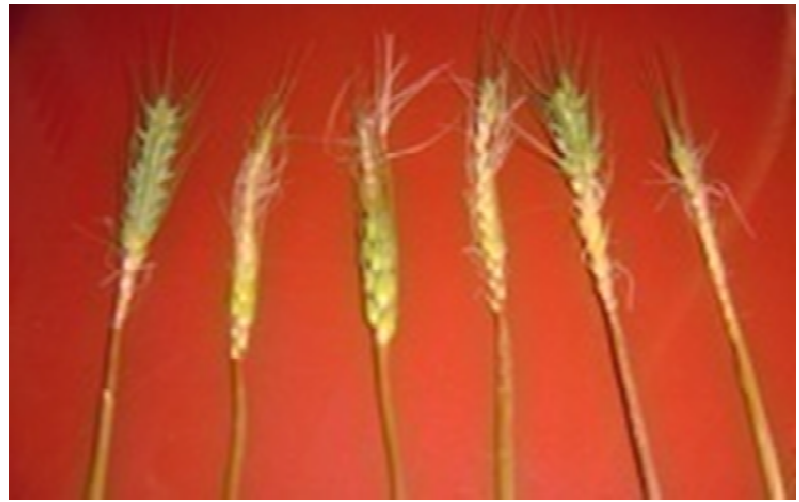

Fig. 5. Damaged wheat spikes when frost occurred at different time of earhead emergence. ( Original photographs taken by one of the author Dr. R. K. Sharma).

cit, such as a drought or high soil salinity. Plants try to adapt to the stress conditions with an array of biochemical and physiological interventions. Moisture stress affects wheat growth from germination till physiological maturity. The stress response in wheat and other crops depends upon the severity of the stress, rate, duration of exposure and the plant developmental stage (Bartel and Bartel, 2003).

The tillage options like zero tillage, No-Till with or without residue retention and FIRB with residue retention on bed reduces the water runoff in the areas of heavy rainfall and undulating land. This reduces the top soil loss which is most fertile and also with residue retention there is build up of organic matter in the soil, ultimately bringing sustainability in production over a period of time. Also ZT helps in lowering the soil temperature and maintains soil moisture content, resulting plant to carry out its metabolic process at the pace required for its optimum growth and development. FIRBS recorded the lowest consumptive use of water

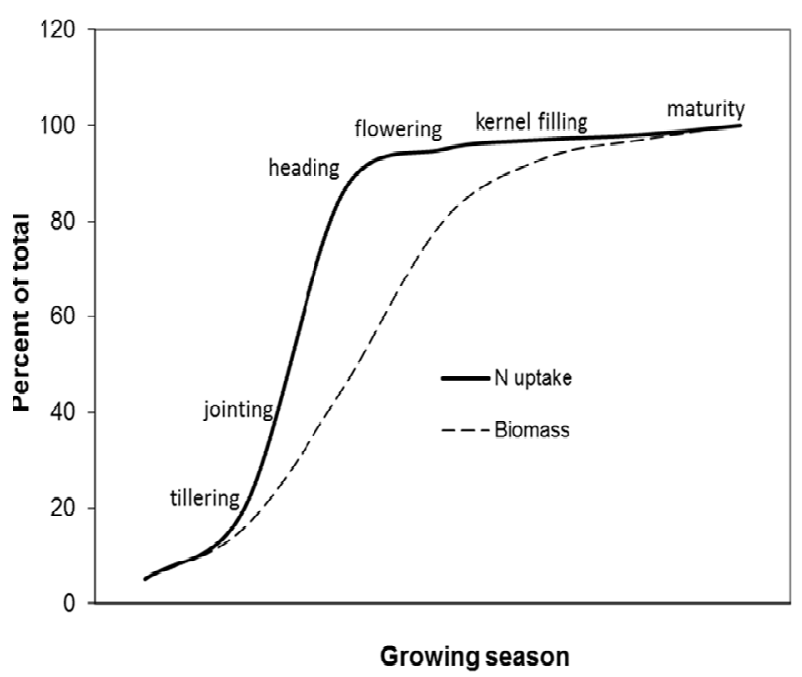

Fig. 6. Percent of total biomass and $N$ uptake during the growing season at various wheat Growth stages (Source: Brown et al., 2005)
$(30.07 \mathrm{~cm})$ and the highest water-use efficiency $(147.6$ $\mathrm{kg} / \mathrm{ha}-\mathrm{cm}$ ) in comparison to other methods of sowing (conventional and side sowing on ridges). Among irrigation schedules, irrigation at CRI $+100 \mathrm{~mm} \mathrm{CPE}$ recorded the highest water-use efficiency $(142.5 \mathrm{~kg} / \mathrm{ha}-$ cm) (Idnani and Kumar, 2013).

The consistent reduction in runoff coefficients in treatment with permanent raised beds with $30 \%$ standing crop residue retention and no-tillage on the top of the bed was due to the capacity of the $25-35 \mathrm{~cm}$ wide furrows to retain a large proportion of runoff as depression storage. Reduced runoff means an improvement in the soil water status in the root zone and a reduction in soil loss, which in turn leads to reduced land degradation and reduced crop water stress (Tesfay et al., 2012). A maximum grain yield of 5.20 tonnes $\mathrm{ha}^{-1}$ was obtained with no water stress treatment. All levels of water stress except $-0.5 \mathrm{MPa}$ during flowering to maturity decreased the grain yield as compared to the no stress treatment. Results indicate that, the wheat crop should be irrigated at $50 \%$ depletion of available soil water (ASW) (Singh et al., 1983). Crops are sensitive to water stress during the reproductive growth stages and yields will be impacted during this time period. When producers have limited water supplies, but have control over when they can irrigate, limiting water during the growth stages that are least sensitive to water stress while saving water for the critical growth stages can be a valuable strategy to maximize yield return from water.

Hence, scheduling irrigation according to growth stages of crop, use of efficient sowing methods, providing extra irrigation if available and irrigation based on moisture status of soil results in maximizing wheat grain yield.

Water logging: Water logging occurs when there is insufficient oxygen in the soil pore space for plant roots to respire. Under such conditions, root harming gases such as carbon di oxide and ethylene gets accumulated in the root zone and thus affects the growth and development of plant. Ethylene is produced both by the roots and by microorganisms in waterlogged soils. Ethylene is known to be a trigger (not a promoter) of leaf senescence (Dong et al., 1983). In the northern Indo-Gangetic Plains of India alone, 2.5 million ha of wheat area are affected by irregular waterlogging (Sharma and Swarup, 1988). The effects of waterlogging are most in regions of South and Southeast Asia. In these countries, rice rotations are practiced on much of the land. Soils are generally puddled to restrict water percolation and create flooded conditions for rice cultivation. Due to soil puddling, wheat that follows rice is planted under less than optimal soil physical conditions. The soil pan that was created intentionally for rice cultivation is often left undisturbed and may create a barrier for water movement, causing waterlogging in case of excessive irrigation or rainfall. Even the Vertisols in high rainfall areas are mostly 
kept fallow during monsoons due to water logging and only one crop is raised during the post-rainy season. Their productivity could be increased by practicing raised sunken bed system that permits raising of two crops. Likewise, the waterlogged alluviums in eastern India have water stagnating above ground for over six months in a year. Because of these adverse physical conditions, only one anaerobic paddy crop with a very low yield potential of less than one tonn $\mathrm{ha}^{-1}$ is taken.

The ill effects of waterlogging can be decreased firstly, by addition of organic manure which improves the physico-chemical properties of soil, reduces soil surface crusting, enhance plant rooting, and alleviate the effects of pan formation on yields. Secondly, by use of FIRB method of planting which make it possible to drain fields or keep a large portion of the root system out of waterlogged soils (Abebe et al., 1992 and Tedia et al., 1994). Thirdly, adopting furrow or sprinkler irrigation on waterlogging prone soils reduces the problem significantly (Melhuish et al., 1991). Fourthly, by using wheat genotypes which getting established once, can withstand waterlogging up to 10 days with no yield loss, if the wheat leaves are not submerged. Generally, the wheat plant's tolerance to waterlogging increases with its age or its stage, and the detrimental effect on yield decreases (Meyer and Barrs, 1988). Once the wheat crop is established, many Also, the wheat crops can make an amazing recovery following early waterlogging stress, if supplied with extra nitrogen.

\section{Temperature stress}

High temperature: High temperature accelerates the growth of crop by making it to enter into jointing stage too early, thus reducing tillering period. This leads to reduction in number of tillers, in turn reducing total crop yield. Similarly, high temperature at flowering and grain filling stage shorten the duration of grain filling resulting in early maturity, thus reducing the crop yield. Existence of high temperature at different developing stages of the crop shortens the time period of that particular stage and thus reduces the accumulation of photosynthates necessary for getting optimum yield. An increase of $0.50^{\circ} \mathrm{C}$ temperature resulted in decrease in duration of crop by seven days, reducing yield by 0.5 tonn ha $^{-1}$ in north India (Parry et al.,1992). Under high tempera-ture, the crop completes its life cycle much faster than un-der normal temperature conditions (Fischer, 1985). The high temperature stress can be mitigated by making changes/ adopting new agronomic practices which are as under:-

Selecting optimum time of planting: It helps in avoiding high temperature stress during anthesis and grain filling. High temperature at this stage shortens the season and reduces yield. Early sowing can avoid frequent hot and strong desiccating winds during grain filling period, because the crop can not transpire fast enough to keep cool which is necessary to protect the crop from temperature stress. The crop sown on 20 November achieved maximum height, dry-matter accumulation plant ${ }^{-1}$ and number of tillers than rest of sowing dates. The reason behind is the availability of maximum growing period length in 20 November sowing than other dates (Jat et al., 2013).

Use of mulch/ Zero tillage- helps to protect seedlings from temperature stress. This keeps soil temperature lower during the day by insulating it from incoming solar radiation and conserving moisture. Mulch also reduces soil cooling at night, the transpiration process get increased with lowering of soil temperature, resulting reduction in the canopy temperature and thus helps in overcoming the terminal heat stress in plant. This delay the maturity period of the crop and thus results in increase in growth attributes and ultimately the yield of the crop. Zero tillage option led to an improvement in yield attributes, viz. plant height, effective tillers $\mathrm{m}^{-1}$, grains per ear as compared to conventional tillage method (Mishra et al., 2011).

Use of sprinkler/drip irrigation: It helps in maintaining adequate soil moisture thereby reduces canopy/soil temperature. The grain yield obtained using drip irrigation was $24 \%$ higher than full irrigation treatment and $59 \%$ higher than the existing rule treatment (Kharrou et al., 2011).

Low temperature: During flowering and initial grain growth of cereals, frost damage reduces the number of kernels per spike. Due to frost thinner band forms on the spikes for each frost event, awns become curly, and spikes are upright near maturity because of less grain weight (Figure 5). Low temperature during anthesis stage increased pollen sterility, thus decreasing germination of pollen grains in both aestivum and durum wheat. In wheat varieties where anthesis took place in the month of December and January face very low temperature leading to more number of sterile pollens and ultimately less yield of wheat crop. This shows that low temperature has profound effect on wheat crop. Early sown wheat crops will be most affected by low temperature because of more chances of occurrence of low temperature during the anthesis stage.

Prevalence of very cold weather can cause sterility as high as $98 \%$ (Subeidi and Budhathoki, 1995, Subedi et al., 1996). After emergence from the flag leaf sheath, wheat ear is highly susceptible to damage by frost (Marcellos and Single, 1984). Freezing temperature can severely injure wheat at its reproductive stage and greatly reduce grain yields. So, there is a need to develop better practices to reduce the harmful effect of cold stress in wheat (Chakrabarti et al., 2011).

Nutrient deficiency/ toxicity: Plants require essential nutrients for normal functioning and growth. A plant's sufficiency range is defined as the range of nutrient necessary to meet the plant's nutritional needs and maximize growth. The width of this range will depend upon individual plant species and the particular nutrient. Nutrient levels outside of a plant's sufficiency range decline overall crop growth and health due to either a deficiency or toxicity.

Nutrient deficiency occurs when an essential nutrient 
is not available in sufficient quantity to meet the requirements of a growing plant. Toxicity occurs when a nutrient is in excess of plant needs and decreases plant growth or quality.

The three basic tools for diagnosing nutrient deficiencies and toxicities are

1) Soil testing

2) Plant analysis

3) Visual observations in the field.

With the introduction of Green revolution in India, no doubt we have become self-sufficient in terms of food grain production. However, imbalanced use of inorganic fertilizers and plant protection chemicals for maximizing yield has resulted in deterioration of physical, chemical and biological health of rice- wheat growing soils. The imbalanced and inadequate nutrient application by farmers has resulted in decrease in wheat production. To maintain the fertility status of soil under high intensity crop production, there is annual replenishment of those nutrients that are removed from the field by the crop. To overcome this problem of nutrient deficiency/ toxicity, one should go for nutrient management like INM, Site specific nutrient management, use of remote sensing etc.

Fertilizers should be applied as per requirement for optimal crop growth and according to agro climatic situations. At the same time, negative impact of external sources should be minimized. Over application of fertilizers, which is neither inexpensive for farmers in developed countries, results in neither substantially greater crop nutrient uptake nor significantly higher, yields (Smaling and Braun 1996). Rather, their excessive use is economically wasteful and can cause damage to the environment. Under application, on the other hand, reduces crop growth and lower down the yield. Improved and adequate application of inorganic and organic fertilizer not only conserves nutrients in the soil, but makes nutrient uptake more efficient.

There are hardly any farm-level practices which are being conducted to monitor nutrient balances in intensively cropped areas. In intensively cultivated areas, soils are being mined and nutrient content of soil is depleting continuously. Nitrogen is costly input and a major share of it is used for cereal cultivation. The cost of nitrogen fertilizers is increasing day by day. Under such a situation, suitable alternative nutrient combinations are to be evaluated. Nitrogen is most important element for optimum functioning of crops (Shivay, 2007) and most crops makes inefficient use of nitrogen. Often less than 50 percent of applied nitrogen is found in the harvest crop. Biofertilizers are eco-friendly and low cost inputs and have tremendous potential for supplying nutrients, which can reduce the inorganic fertilizer dose by 25-50\% (Vance 1997 and Ranaet al.2012). Also, FYM is a good source of nutrients and contributed towards build up of organic matter in soil (Das et al.2008). Application of FYM @ 5 and 10 tonnes ha ${ }^{-1}$ increased the grain and straw yield significantly by 16.1 and $15.5 \%$ and 26.1 and $24.8 \%$, respectively over no FYM during 2006-07. The corresponding increases in grain and straw yield during 2007-08 were 15.3 and $13.8 \%$ and 26.4 and $24.7 \%$. The improvement in grain and straw yield with the application of FYM was owing to the beneficial effect of FYM on nutrient uptake, crop growth rate and yield attributing components (Singh et al., 2013).

Using site specific nutrient management practice average wheat yield was $3.7 \mathrm{t} \mathrm{ha}^{-1}$, which was $23 \%$ higher than the recommended dose of fertilizers and $39 \%$ than that with adoption of farmer practice. Also, with site specific nutrient management practice we get an additional net income of Rs. $3060 \mathrm{ha}^{-1}$ and Rs. 4545 ha $^{-}$ 1 over recommended dose of fertilizers and farmer practice, respectively (Maiti et al.,2006).

The use of pocket sensor has excellent utility in making nitrogen recommendations. There was reduced $N$ application and increased farmer profits by using sensor based nitrogen management. Using GreenSeeker sensors, the average rate of $N$ application was 69 $\mathrm{kgNha}^{-1}$ less than that of the farmer practice (OrtizMonasterio and Raun, 2007). For efficient use of nitrogen, the nitrogen fertilizer should be applied according to the $\mathrm{N}$ uptake and stage of the wheat crop. Cumulative nitrogen uptake in wheat follows a sigmoid (or " $S$ " shaped) curve giving rise to the three phases (Figure6). Nitrogen uptake is slow during the early growth phase from emergence into tillering (Phase1).Rapid accumulation of nitrogen occurs in Phase II, corresponding stem elongation phase from jointing to heading. Maximum $\mathrm{N}$ uptake occurs during this period and reaches $2-3$ pounds per day with total uptake of approximately 100 to 150 pounds of $\mathrm{N}$ per acre or more depending on the yield potential (Brown et al., 2005). The plant accumulates most of the $\mathrm{N}$ up to boot stage. Uptake slows during the third phase i.e. flowering to maturity.

Hence, proper nutrient management techniques are required to correct nutrient deficiency /toxicity in wheat crop, there by maintaining soil physical, chemical and biological properties thus bringing sustainability in crop production.

Depleting water quality: In arid and semi-arid regions of the country, scarcity of good quality irrigation water is a major limiting factor for crop production. While irrigated agriculture has greatly increased crop productivity, inappropriate and inefficient use of irrigation water has resulted in polluting surface water and groundwater, damaged productivity and altered the ecology of vast areas of land. Indiscriminate use of fertilizers, herbicides and pesticides has contaminated surface and groundwaters in many areas. In India an estimated 32 billion of the 135 billion cubic meters of groundwater withdrawn annually are saline (Minhas and Samra, 2003). Saline groundwater results from reactions that occur as water moves through the soil profile and from reactions that occur within groundwa- 
ter layers. Irrigating with saline groundwater can degrade land quality, causing long-term impacts on crop growth and yields.

Mixing saline water with fresh water reduces the potential usability of the total water supply. To combat with this problem of saline water usage in agriculture, new techniques need to be developed and implemented. To reduce excessive water uses and conserve the limited water supplies, better ways must be found to implement existing methods more effectively. The reuse of wastewater, including drainage water and shallow saline groundwater for crop production, must be made an integral component of irrigation water management system. Effective salinity control measures must be developed and implemented to sustain irrigated agriculture and to prevent pollution of associated water resources.

To prevent the excessive accumulation of salt in the root-zone from irrigation, extra water (or rainfall) must be applied in excess of that needed for ET requirement of crop. Artificial drainage systems must be used in the absence of adequate natural drainage. The water table depth required to prevent a net upward flow of water and salt into the root-zone is dependent on irrigation management and is not single-valued as is commonly assumed (Schilfgaarde, 1976).

Management practices for the safe use of saline water for irrigation consist of: i) Selection of crops or crop varieties that are tolerant to salinity or sodicity ii) Special planting methods to minimize salt accumulation in the vicinity of the seed iii) Irrigation to maintain a high level of soil moisture and periodic leaching of salts in the soil iv) Use of land preparation methods for uniform distribution of water and to increase infiltration, leaching and removal of salts v) Special treatments such as tillage and additions of chemical amendments, organic matter and growing green manure crops should be used to maintain soil permeability and tilth.

Use of micro-irrigation systems such as drip and sprinklers, helps in better control on salt and water distributions and thus enhanced the use efficiency of saline water especially for high value crops. Preemergence application of saline water through sprinklers, lowers the concentrations of soluble salts in seedbed during germination and resulted in better crop estalishment. As the germination and seedling establishment stages have been identified as the sensitive stages in most crops, so better quality water should be utilized for pre-sowing irrigation and during early stages of crop growth. Then we can switch over to poor quality water when the crops can tolerate higher salinity.

The sprinkler method of irrigation was superior to check basin method in getting enhanced yield of crops under sodic soil and water conditions (Sidhpuria et al., 2006). Addition of Gypsum @ 75\% to neutralize sodic water resulted in getting optimum yield in wheat using sprinkler method of irrigation (Singh et al., 2002).
Drip irrigation, is recommended for use of saline irrigation water as it reduces salinity and matric stresses in the rootzone, though salts accumulate in the periphery of the wetted area. Additional water must be applied, to leach out the salt that has accumulated during previous irrigations. The leaching requirement mainly depends on salt content of the irrigation water and on the maximum salt concentration permissible in the soil solution which in turn depends on the salt tolerance of the crop and the method of irrigation.

Crop lodging: In recent years, lodging is reported to be the most limiting factor in attaining higher wheat yields (Ransom, 2005). It can cause yield losses up to $40 \%$ if occurs during the 10 days after heading (Kelbert et al.,2004). Previous results suggest that lodging is induced due to inadequate standing power of the crop and adverse weather conditions, such as rain, strong winds, and hail, especially in the last phase of the crop's growth (Rawson and Macpherson, 2000). Lodging of irrigated wheat can be controlled through crop management practices and cultivar improvement. Bed planted genotypes resulted over 50\% less lodging compared with flat planting (Tripathi et al., 2005). Wheat grown on beds has less lodging effect due to more vigorous stem development and also enables to exploit potential yield (Tripathi et al., 2002, 2005). Lodging was due to high velocity winds in February, March and April (71, 69 and $72 \mathrm{Km} / \mathrm{h}$ ) coupled with rainfall especially in February and March (143 and 115 $\mathrm{mm}$ ) at milky stage of the crop. The situation further aggravated due to soil textural class (silty clay), which created temporarily water logged condition and thus favour root lodging of the crop. Care should be taken while applying the final irrigation to wheat that might be light $\&$ at early grain filling stage (Khakwani et al., 2010). Pinthus (1973) found that wheat crop sown under no till condition lodges less as compared to the crops grown on well ploughed land.

Maintaining lower plant density helps in reducing lodging. Berry et al., 2000 found that by maintaining 200 wheat plants $\mathrm{m}^{-2}$ as compared to 400 wheat plants $\mathrm{m}^{-2}$ reduces the lodging risk by increasing the strength of the anchorage system by more than $50 \%$ and the strength of the stem by $15 \%$. The properties of soil have also been found to have an important effect on lodging, as it has been predicted to be directly proportional to anchorage strength of the crop. A model of soil strength developed by Baker et al., 1998 showed that variation in clay content, moisture content and compaction alters the soil shear strength by manyfold. Another reason of crop lodging is application of more nitrogen fertilizer and could be due to its primarily effect on the basal culm internodes. Increasing nitrogen dose resulted in 10-25 per cent increase in length of basal internodes (Garg et al., 1973; Pinthus, 1973; Knapp et al., 1987; and El Debaby et al., 1994). The N nutrition had a direct impact on strength of wheat culm. On an average, strength of stems was 20 per cent 
weaker at $240 \mathrm{~kg} \mathrm{~N} \mathrm{ha}^{-1}$ compared to $160 \mathrm{~kg} \mathrm{~N}^{-1}$ application (Crook and Ennos, 1995). In another study Garg et al.(1973) observed that the application of 200 $\mathrm{kg} \mathrm{N} \mathrm{ha}{ }^{-1}$ decreased the breaking strength of $2^{\text {nd }}$ internode compared at lower $\mathrm{N}$ levels. Crop lodging can also be reduced by the use of growth retardants. Use of Ethephon at $0.28 \mathrm{~kg} \mathrm{a} \mathrm{i} \mathrm{ha}^{-1}$ at DC 41 to 43 resulted in significant decrease in the length of peduncle, middle internode and also to some extent basal internode compared to internode lengths of control plot (Knapp et al., 1987). Growth retardants, besides reducing plant size, allows better nutrient utilization by the plant in response to physiological changes (Buzetti et al., 2006, Espindula et al., 2009a).

Hence, lodging in wheat can be reduced by use of lodging resistant cultivars, planting method, restricting nitrogen fertilizer application, irrigation management at maturity stage and use of growth retardants.

\section{Conclusion}

To meet the food demand of ever growing population, there is need to reduce yield losses due to various abiotic stresses like problematic soils, temperature stress, moisture stress, depleting water quality, waterlogging, nutrient deficiency/ toxicity, crop lodging etc because of changing climatic conditions and exhaustive use of natural resources. For this better understanding of abiotic stresses and the ways to alleviate their adverse effects is of immense importance. The abiotic stresses could be managed to a great extent by adopting suitable agronomic management practices like adjusting the time of sowing, selection of resistant genotypes, selection of appropriate planting method with respect to edaphic and climatic conditions of the area. In addition, adopting conservation agriculture practices like no-till with or without crop residues coupled with micro-irrigation systems like sprinkler and drip irrigation, soil amendments, integrated and sitespecific nutrient management can play a major role in increasing the crop productivity.

\section{REFERENCES}

Abebe M., Mamo T., Duffera M., and Kidanu S. (1992). Durum wheat response to improved drainage of Vertisols in the central highlands of Ethiopia. In: D.G. Tanner and W. Mwangi, (eds.). Seventh Regional Wheat Workshop for Eastern, Central and Southern Africa. Nakuru, Kenya: CIMMYT: 407-414.

Abrol I.P., Yadav, J.S.P. and Massoud F.I., (2012). SaltAffected Soils and their Management, refer para 4.7". Retrieved 23 December 2012.en.wikipedia.org/wiki/ Residual sodium_carbonate_index.

Baker C.J., Berry P.M., Spink J.H., Sylvester-Bradley R., Clare R.W., Scott R.K., Griffin J.M. (1998). A method for the assessment of the risk of wheat lodging. Journal of Theoretical Biology. 194: 587-603.

Bartel, B. and D.P. Bartel (2003). Micro RNAs: at the root of plant development? Plant Physiol. 132: 709-717.

Berry P.M., Griffin J.M., Sylvester-Bradley R., Scott R.K., Spink J.H., Baker C.J. and Clare R.W. (2000). Control- ling plant form husbandry to minimise lodging in wheat. Field Crop Research. 67: 59-81.

Bolt G.H (ed.) (1981). Soil chemistry: A. basic elements. Elsevier, Amsterdam, The Netherlands, 5a.en.wikipedia.org/ wiki/Alkali_soils.

Brown B., Westcott M., Christensen N., Pan B., and Stark J. (2005). Nitrogen Management for Hard Wheat Protein Enhancement. Pacific Northwest Extension publication, PNW578. www.plantbreeding.wsu.edu/pnw0578.pdf.

Buzetti Salatiér, Bazanini Graciela Cristina, Freitas José Guilherme de, Andreotti Marcelo, ArfOrivaldo, Meira Marco Eustáquio de Sá e Flávia de Andrade (2006). Response of rice cultivars to nitrogen and growth regulator chlormequat chloride. Pesq. Agropec. Bras., Brasilia. 41(12): 1731-1737.

Chakrabarti B., Singh S.D., Nagarajan S.and Aggarwal P.K. (2011). Impact of temperature on phenology and pollen sterility of wheat varieties. Australian journal of crop Sciences. 5(8):1039-1043.

Chhabra R. (1996). Soil Salinity and Water Quality. Oxford\&IBH Publishing Co. Pvt. Ltd., New Delhi (South Asian edition) and A.A. BalkemaUitgevers BC, Rotterdam (edition elsewhere). ISBN 81-204-1049-1: 284.

Chris GazeyA. and Joel AndrewB. (2010). Getting the soil pH profile right helps with weed control and sustainability: 2010 19th World Congress of Soil Science, Soil Solutions for a Changing World1 - 6 August 2010, Brisbane, Australia. Published on DVD.www.iuss.org/19th\%20WCSS/ Symposium/pdf/0700.pdf.

Crook M.J. and Ennos A.R. (1995). The effect of nitrogen and growth regulators on stem and root characteristics associated with lodging in two cultivars of winter wheat. Journal of Experimental Botany. 46: 931-938.

DAFWA Bulletin 4784 "Soil Acidity - A Guide for WA farmers \& consultants", and the WA Soil Quality website www.soilquality.org.au/factsheets (accessed on 3rd August, 2015).

Das A, Shivay Y. and Prasad M. (2008). Production potential and economic evaluation of cotton - wheat cropping system as influenced by prilled urea, Azotobacter and farmyard manure under Indo-Gangetic plains. Journal of Sustainable Agriculture. 32 (1): 37-50.

Dong, J.G., Z.W. Yu, and S.W. Yu. (1983). Effect of increased ethylene production during different periods on the resistance of wheat plants to waterlogging. Acta Phytophysiologia Sinica. 9:383-389.

El Debaby A.E., Ibrahim K.E., Saad A.M.M. and El Salhy T.S. (1994). Wheat lodging and growth characters as affected by some agricultural practices. Annals of Agricultural Sciences. 32: 1325-1337.

EspindulaMarcelo Curitiba, Rocha ValterleySoares, Fontes Paulo CezarRezende, Corrêa da Silva Raul Carvalho and Souza Leandro Torres de (2009). Effect of nitrogen and trin exapac-ethyl rates on the SPAD index of wheat leaves. Journal of Plant Nutrition 32 (11): 1956-1964.

Fageria N.K. and Baligar V.C. (2003). Methodology for evaluation of lowland rice genotypes for nitrogen use efficiency. Journal of Plant Nutrition. 26: 1315-1333.

Fageria N.K. and Baligar V.C. (2005). Enhancing nitrogen use efficiency in crop plants. Advances in Agronomy. 88:97-185.

FAO (2010). Food and Agriculture Organisation of the united nations FAO soils poratal www.fao.org/ soils-portal/soil... of-some-soils/...salt-affected-soils/en (accessed on 7 July, 2015).

FAO (2014). Food and Agriculture Organisation of the 
united nations statistics division www. Faostat3.fao.org/ browse/q/*/e (accessed on 2 July, 2015).

Fischer R.A. (1985). Number of kernels in wheat crops and the influence of solar radiation and temperature. Journal of Agricultural Sciences. 105:447-461.

Garg O.K., Singh R.H. and Tiwari B. (1973). Physiological significance of nitrogen nutrition in relation to lodging in wheat. Field Crop. 26: 1527.

Grieve, C.M, Francois L.E. and Poss J.A. (2001). Salt stress during early seedling growth on phenology and yield of spring wheat. Cereal Res. Comm.:167-174

Idnani L.K. and Kumar Ashok (2013). Performance of wheat (Triticum aestivum) under different irrigation schedules and sowing methods. Indian Journal of Agricultural Sciences. 83 (1): 37-40.

Jat Lokesh Kumar, Singh S.K., Latare A.M., Singh R.S. and Patel C.B. (2013). Effect of date of sowing and fertilizer on growth and yield of Wheat in an Inceptisolof Varanasi. Indian jounal of Agronomy. 58(4): 611-614 .

Kanyanyua S.M., Ireri L., Wambua S., Nandwa S.M. (2002). Acidic soils in Kenya; Constraints and Remedial options. KARI Technical Note No. 11; KARI Headquarters, Nairobi, Kenya.www.kari.org/fileadmin/publications/tech_notes/ tecnote11.pdf.

Kelbert, A.J., Spaner D., Briggs K.G. and King J.R. (2004). Screening for lodging resistance in spring wheat breeding programmes. Plant Breed. 123(4): 349-354.

Khakwani Abdul Aziz, Baloch mohammadSafdar, Nadim Muhammad Amjad, ZubairMuhammad,H. Shah Inayat and WahabKhan Abdul (2010). Lodging: a determining factor in reducing yield and yield structure of wheat. Sarhad Journal of Agriculture 26( 2).

KharrouMoh. Hakim, Er-Raki Salah, Chehbouni Ahmed and Duchemin Benoit (2011). Water use efficiency and yield of winter wheat under different irrigation regimes in a semi - arid region, Agicultural Sciences. 2: 273-282.

Knapp J.S., Harms C.L. and Volence J.J. (1987). Growth regulator effects on wheat culm non structural and structural carbohydrates and lignin. Crop Science. 27: $1201-1205$.

Kochian L.V., Hoekenga O.A., Pineros M.A. (2004). How do crop plants tolerate acid soil Mechanisms of aluminum tolerance and phosphorus efficiency. Ann. Rev. plant biol. 55:459-493.

Lauchli, A. and Epstein E. (1990). Plant responses to saline and sodic conditions. In K.K. Tanji (ed). Agricultural salinity assessment and management. ASCE manuals and reports on engineering practice . 71: 113-137.

Ligeyo D.O., Gudu S.O. (2003-2005). Further laboratory screening of More Kenya Maize Inbred lines for Tolerance to Aluminum In: Third year Progress Report, (March 2004 to 28February 2005). Mcknight Foundation USA Project, EMBBRAPA, Purdue and Cornell University (USA) and Moi University (Kenya) Phasel.

Maiti D., Das D.K. and Pathak H. (2006). Fertilizer requirement in irrigated wheat in Eastern India using requirement in irrigated wheat in Eastern India using requirement in irrigated wheat in Eastern India using the QUEFTS simulation model. The Scientific World. 6: 231-245.

Marcellos H. and Single W.V. (1984). Frost injury in wheat ears after ear emergence. Aust. J. Plant. Physiol., 11: 7-15.

Melhuish, F.M., Humphreys E., Muirhead W.A., and White R.J.G. (1991). Flood irrigation of wheat on a transi- tional red-brown earth. I. Effect of duration of ponding on soil water, plant growth, yield and N uptake. Australian Journal of Agricultural Research. 7: 1023-1035.

Meyer, U.S., and Barrs H.D. (1988). Response of wheat to single short-term waterlogging during and after stem elongation. Australian Journal of Agricultural Research. 39:11-20.

Minhas, P.S., and Samra J.S. (2003). Quality Assessment of Water Resources in the Indo-Gangetic Basin Part in India. Karnal, India: Central Soil Salinity Research Institute: 68 .

Mishra Santosh Kumar, Tripathi D.K., Srivastava N.K., Beg M.Z. and Singh C. (2011). Effect of different level of nitrogen on Wheat after rice under Zero tillage, Indian J. Sci. Res.I. 2(3): 97-100.

Mohwbbi S. and Mahler R.L. (1988). The effect of soil pH manipulation on chemical properties of an agriculyural soil from Northern Idaho. Commun. Soil sci. plant annal . 19(15): 1795-1812

Mora, M.L., Cartes, P., Nunez, P., Salazar, M. and Demanet, P. (2007). Movement of $\mathrm{NO}_{3}{ }^{-}-\mathrm{N}$ and $\mathrm{NH}_{4}{ }^{+}-\mathrm{N}$ in an andisol and its influence on ryegrass production in a short term study. R. C. Suelo Nutr. Veg. 7:46-64.

Oerke E.C., Debne H.W., Schonbeck F. and Weber A. (1994). Crop production and crop protection. Amsterdam: Elsevier: xxii+ 800 pp.

Ortiz-Monasterio J. I. and Raun W. (2007). "Reduced nitrogen and improved farm income for irrigated spring wheat in the Yaqui Valley, Mexico, using sensor based nitrogen management," Journal of Agricultural Science. 145: 1-8,

Parry M.L., Swaminathan M.S. (1992). Climate on food production.Mintzer (ed) confronting climate changerisk, implication and responses. Cambridge University press: $113-125$

Pinthus M.J. (1973). Lodging in wheat, barley and oats: The phenomena, its causes andpreventive measures. Advances in Agronomy. 25: 209-263.

Poschenrieder, C., Gunse, B., Corrales, I. and Barcelo, J. (2008). A glance into aluminium toxicity and resistance in plants. Sci. Total Environ. 400:356-368.

Provin Tony and Pitt J.L. (2001). Managing Soil Salinity, Texas A\& M Agri life extension service Publications, [5] E-60: 3-12.

Rana A., Joshi M., Prasanna R., Shivay Y.S. and Nain L. (2012). Biofortification of wheat through inoculation of plant growth promoting rhizobacteria and cyanobacteria. European Journal of Soil Biology. 50: 118-26

Ransom, J. (2005). NDSU Extension Agronomist - Cereal Crops. Joel.ransom@ndsu.nodak.edu

Rawson, H.M. and Macpherson H.G. (2000). Irrigated wheat: Managing your crop. FAO, Rome.

Sharma, D.P. and Swarup A. (1988). Effect of short term waterlogging on growth, yield and mineral composition of wheat in sodic soils under field condition. Plant and Soil. 107:137-143

Sharma, K.L., Mandal, B. and Venkateswar B. (2012). Soil quality and productivity improvement under rainfed conditions- Indian perspectives. Resource management for sustainable agriculture http://dx.doi.org/10.5772/45870 pp: 203-238.

Shivay Y. S. (2007). Effect of levels and neem (Azadirachta indica Juss) coated urea sources of nitrogen on productivity and nitrogen recovery of rice under Indo-Gangetic plains. International Journal of Tropical Agriculture. 25 
(4): 111-123.

Sidhpuria, M.S., Singh, Jagdev and Yadav, S.S. (2006). Comparative performance of various irrigation methods in cotton crop. Haryana Journal of Agronomy. 22: 179180.

Singh Tej and Malik D.S. (1983). Effect of water stress at three growth stages on the yield and water -use efficiency of dwarf wheat. Irrigation Science. 4: 239-245.

Singh Vinay, Singh S.P., Singh Sandeep and Shivay Y.S. (2013). Growth, yield and nutrient uptake by wheat (Triticum aestivum) as affected by biofertilizers, FYM and nitrogen. Indian Journal of Agricultural Sciences. 83 (3): 331-334.

Singh, S., Balyan, D.S., Yadav, A.C., Rana, M.K. and Singh, N. (2002). Influence of FYM and gypsum in reducing the adverse effect of sodic water on attributes related to yield and quality of potato. Haryana Journal of Horticultural Sciences. 32: 123-126.

Smaling E. M. A. and Braun A. R. (1996). Soil fertility research in Sub-Saharan Africa: New dimensions, new challenges. Communications in Soil Science and Plant Analysis. 27 (3/4): 365-386.

Subedi K.D. and Budhathoki C.B. (1995). Wheat sterility problem in Nepal: research at Lumle Agricultural Research Center. In: Bell, R.W., Rerkasem, B. (Eds.), Causes of sterility in Wheat, Environmental Science Report 94/6. Murdoch University, Western Australia: 44-55.

Subedi K.D., Budhathoki C.B., Subedi M., Sthapit B.R. (1996). Overview of wheat sterility problem and research findings to-date in the Western hills of Nepal. In: Rawson, H.M., Subedi, K.D. (Eds.), Sterility in Wheat in Subtropical Asia: Extent, Causes and Solutions. Proceedings of a Workshop held from 18-21 September,
1995 at Lumle Agricultural Research Center, Nepal. ACIAR Proceedings. 72: 119-126.

Tedia, A., Sherington J., and Mohamed SaleemM.A. (1994). Integration of forage and food crops grown sequentially on Vertisols under rainfed conditions in the mid-altitude Ethiopian highlands. Experimental Agriculture .30: 291-298.

Tesfay Araya WeldeslassieUGent, Wim CornelisUGent, Jan NyssenUGent, Bram Govaerts, FekaduGetnet, Hans Bauer, Kassa Amare, Dirk Raes, mitiku Haile and Jazef Deckers (2012). Medium-term effects of conservation agriculture based cropping systems for sustainable soil and water management and crop productivity in the Ethiopian high lands. Field Crops Research. 132: 53-62.

Thilert W. (2006). A unique product: The story of the imidadopid stress shield. P flanzenschutz- Nachrichten science Forum, Baye.r 59: 73-86.

Tripathi S.C., Sayre K.D., Kaul J.N. and Narang R.S. (2002). Effect of planting methods and $\mathrm{N}$ rates on lodging, morphological characters of culm and yield in spring wheat varieties. Cereal Research Communication.s 30 (3-4):431-438.

Tripathi, S.C., Sayre K.D. and Kaul J.N.. (2005). Planting systems on lodging behavior, yield components, and yield of irrigated spring bread wheat. Crop Sci. 45(4): 1448-1455.

Tsadilas C.D., Samaras V., Varvarousis J., Maslaris N (1995). Liming of acid soils.I. Influence on wheat yield and availability of soil nutrients. ID No. 128 Session 10 - soil fertility: 10-91.

Vance C.P. (1997). Biological fixation of N2 for ecology and sustainable agriculture. Springer-Verlag: 179-186.

USDA (2014). Retrieved from www.fas.usda.gov/psdonline.

VanSchilfgaarde J. (1976). Water management and salinity. In: Prognosis of salinity and alkalinity. Soils Bulletin No. 31. FAO, Rome. 